\title{
The Business Opportunities and Constraints within the Printing and Graphic Arts Industry: A Study on Sylhet City
}

\section{Md. Moniruzzaman Muzib ${ }^{1}$, Md. Mizanur Rahman²}

${ }^{1}$ Lecturer, Department of Economics, Mawlana Bhashani Science \& Technology University, BANGLADESH ${ }^{2}$ Graduate Student, Department of Business Administration, Shahjalal University of Science \& Technology, BANGLADESH

\begin{abstract}
This paper investigates the growing competitive printing and graphic arts industry in Sylhet focusing on the investment process, employment opportunity, government support, and the others crucial factors of market that are responsible in determining the industry volume through some statistical analysis. By looking on the opportunity and constraints of this industry, it addresses the preference of the customers as well as the limitation and potential for growth. Statistical significant association was tested by tools like descriptive analysis through the primary data, SWOT analysis etc. to examine the relationship of the considered variables and the prospect and constrictions of this industry has been analyzed with recommendation.
\end{abstract}

Keywords: Printing, Press, Graphic Arts, Opportunities, Constraints, Sylhet JEL Classification Code: M00

\section{INTRODUCTION}

In modern age printing and graphic arts is a buzzword for all developed and developing countries like earlier. Because it is just not a part of the business for income of nations, it is a power on which developments run smoothly. Printing and graphic arts is that kind of appliance by which knowledge can share and ensured the development. Without printing and graphic arts sector developments never are imagined by any developing or developed country. The uniformly respectable commodity, the first assembly line and very particularly the first mass production line have been developing because of the invention of printing (McLuhan, 1962). In the same time, physical and technological sense of the printing press was invented, and the press creates a new historical stage of world development (Weber, 2006).

In today's developed world the popularity of online newspaper, books, catalogues and business document are increasing and so that printing demand is declining, but in some cases this demand also increase. To meet the challenges, the printing firms respond in 
various ways. Most of the firms take up digital printing (IBSA, 2013). The printing industry is facing huge prices going down, some through greater efficiency and some through competition, and the price of the printing industry has been going down continuously (Smyth, 2010). For better business they (IBSA, 2013) suggest that, improve relation with the customer, offering online service, ensure customer benefits, improve internal communication, improve management and HR tasks. Though, current and traditional product of printing industry facing challenges and it will be going on. Skilled printing firms can adopt with this, and the lacking firms need courage to meet the challenges (Vehmas et al., 2011)

This study argues that printing and graphic arts business is a crucial business sector of the current situation of the Sylhet, because of the immerging the city in a new way. How easily the investors take advantage to reduce existing constraints in the business of printing and graphic arts. Our article describes massive impact of opportunities and constraints of the business sector development of the printing and graphic arts, and by the way development of the economy. To figure out the level of present status, we identified some features of opportunities and constraints that will act as the parameter of triumph of printing and graphic arts industry in Sylhet. Our empirical data illustrate the scope of opportunities and reduction of constraints within the industry. The secondary objective of this article is to point out the dilemma of investment and to improve the mutual condition on the overview of the printing and graphic arts sectors' opportunities and constraints within its industry in our area of study.

\section{Methodology}

The methodology of the study based on the quantitative method, and for those we consider 36 printing press and 17 graphic arts firm from Sylhet city as our respondent on the basis of simple random sampling. A semi-structured questionnaire used for data collection and the population size is 117 , and the sample interval is 2.20 .

\section{Present Situation of Printing and Graphic Arts Industry}

The printing and graphic arts industry has seen a remarkable rapid development of the industry in the late 1990's. In Bangladesh, there are more than 7500 printing press among of them 3,000 in Dhaka (Rahman, 2011), and the government of Bangladesh owned two printing presses. These are- The Security Printing Corporation (Bangladesh) Limited and Bangladesh Government Printing Press Limited. Japan-Bangladesh Security Printing \& Papers Limited is the largest private printing press in Bangladesh. And, Bangladesh export printing product to countries like USA, Australia, Sri Lanka and Pakistan (Rahman, 2011). And almost 2000 printing houses are capable of competing with foreign printing houses. The current market size of the printing industry is over 3000 crores and out of which 156 crores is export oriented. More than 0.4 million people are engaged in this sector (BMSS, 2014). A 5-7 years tax holiday is provided to foreign direct investment and full repatriation of invested capital, profit and dividend are available according to law and regulation of Bangladesh government. In Sylhet, most of the firm has been established in last 10-15 years ago, and the customer responsiveness is medium but on the basis of seasonality that is growing high. Sylhet has less supported business firm than that of Dhaka, here is only three printing pre-press supported business firms (commonly known as, positive-output maker). These are-Cosmic Dots, Sylhet Output and Digital Output. 


\section{FINDINGS}

\section{Current Financial Condition}

Financial condition of this industry is fair enough. About 60.38 percent firms are making profit while only 16.98 percent are making loss in their business.

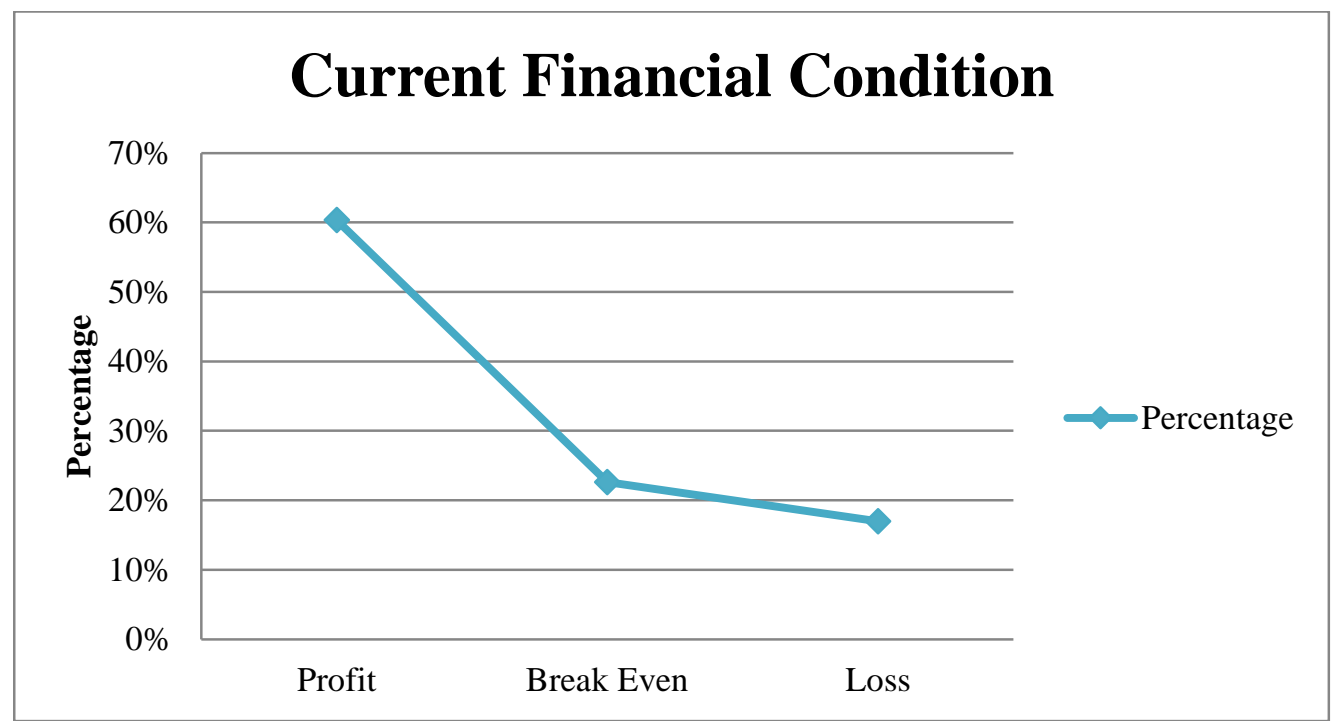

Figure 1: Current Financial Condition

(Source: Field Survey)

\section{Initial Investment in Business}

Initial investment in the printing and graphic arts industry in Sylhet is not good at all. About 50.94 percent investors invest less than 50,00,000 BDT. And only 1.89 percent of investor can invest more than 10 million BDT.

\section{Initial Investment in Business}

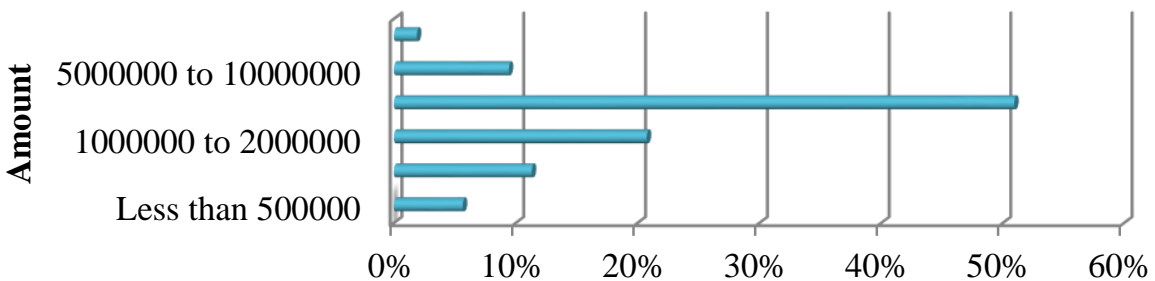

Number of Companies (\%)

\section{Figure 2: Initial Investment in Business} (Source: Field Survey)

And most of the investors are facing the problem of corruption. The data shows that about 90.75 percent of the investor is affected by that. And another significant problem is capital accumulation. Here, more than 79.25 percent investors are facing this problem. 
Table 1: Problems in Investment

\begin{tabular}{|l|c|}
\hline Problems In Investment & Frequency \& Percentage \\
\hline Capital Accumulation & $42(79.25 \%)$ \\
\hline Excess Govt. Regulation & $24(45.28 \%)$ \\
\hline Fund Transfer & $11(20.75 \%)$ \\
\hline Insufficient Bank & $28(52.83 \%)$ \\
\hline Corruption & $48(90.57 \%)$ \\
\hline Others & $18(33.96 \%)$ \\
\hline No Problems & $05(09.43 \%)$ \\
\hline
\end{tabular}

(Source: Field Survey)

\section{Number of Employees}

Employees are an important factor in printing and graphic arts. Most of the firms require none other than qualified employees. About 33.96 percent printing firms have less than 06 employees.

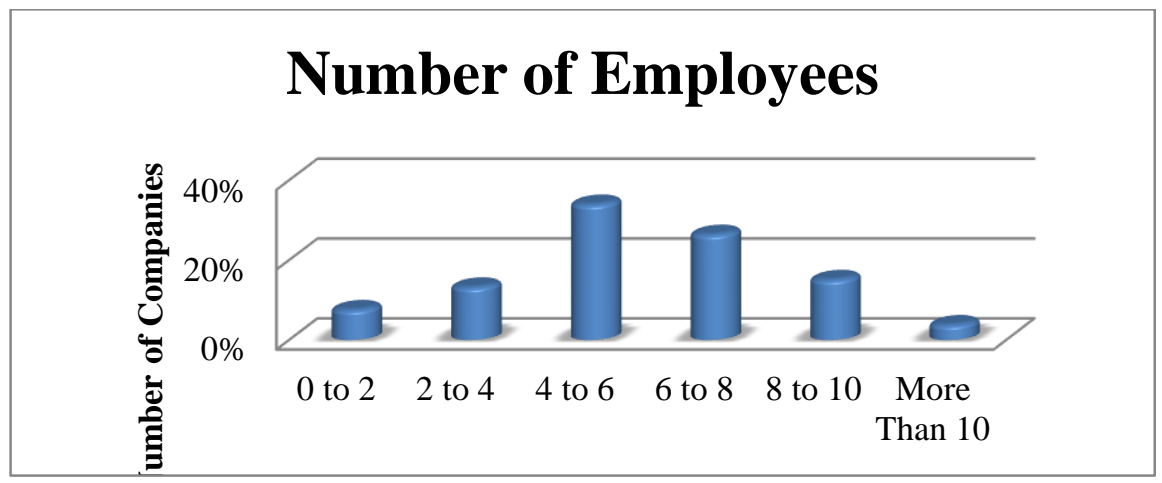

Figure 3: Number of Employees

(Source: Field Survey)

\section{Rate of Return on Investment}

Rate of return of this industry is satisfactory. Most of the firms, 33.96 percent are generating $20 \%$ to $50 \%$ return on investment where 13.21 percent firms are getting losses, and 22.64 percent firms are stays in the break-even point. Hence, we can say that, the printing and graphic art industry in Sylhet generating profit.

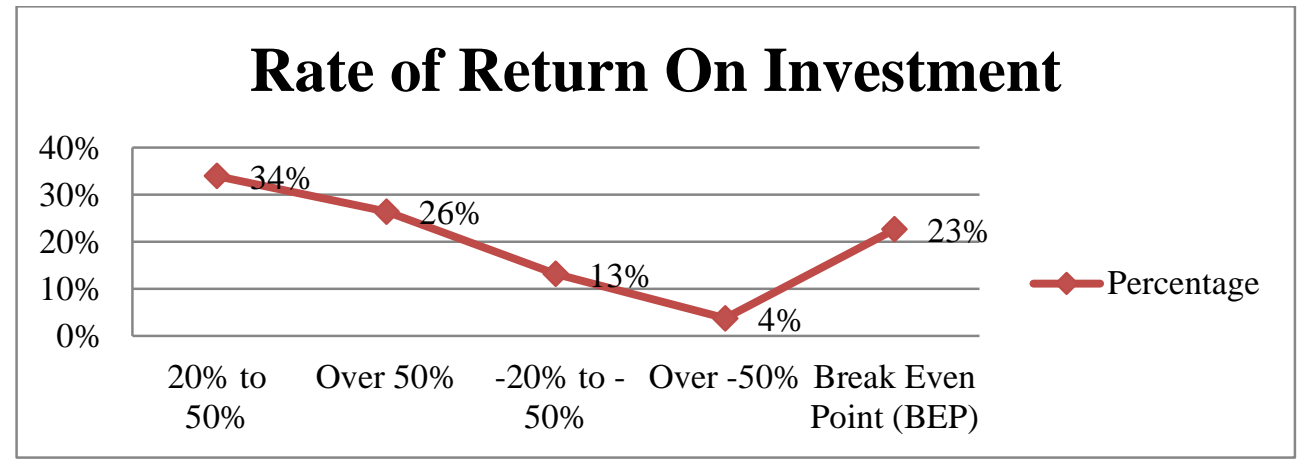

Figure 4: Rate of Return on Investment

(Source: Field Survey) 


\section{Government Support}

Government support is crucial for the development of this industry. But only 28.30 percent firms get government support. Government supports the industry in various ways. Government provides reduction of tax, advisory support and special priority as supporting tools.



Figure 5: Type of Government Support

(Source: Field Survey)

About $60 \%$ of the firm get tax holiday from the government, $53.33 \%$ of the firm get government advisory support, $20 \%$ firm get special priority in various cases.

\section{Problem in Business Operations}

Several types of problems are proceeding in business operations. Insufficient accessories are one of the main difficulties in investment. About 96.23 percent investors are facing this difficulty.

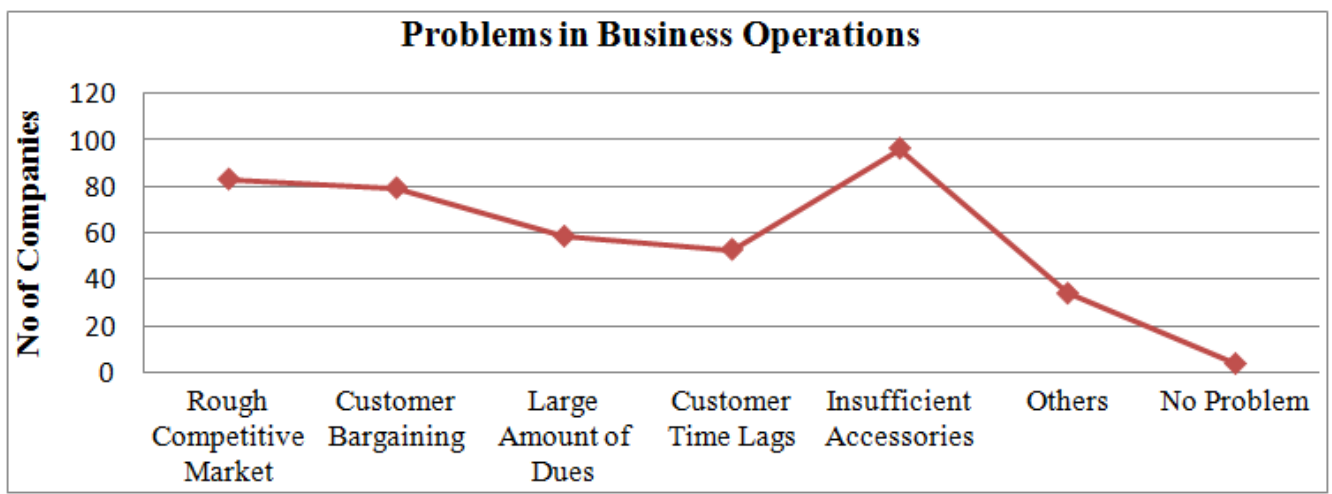

Figure 6: Problems in Business Operations

(Source: Field Survey) 


\section{SWOT Analysis}

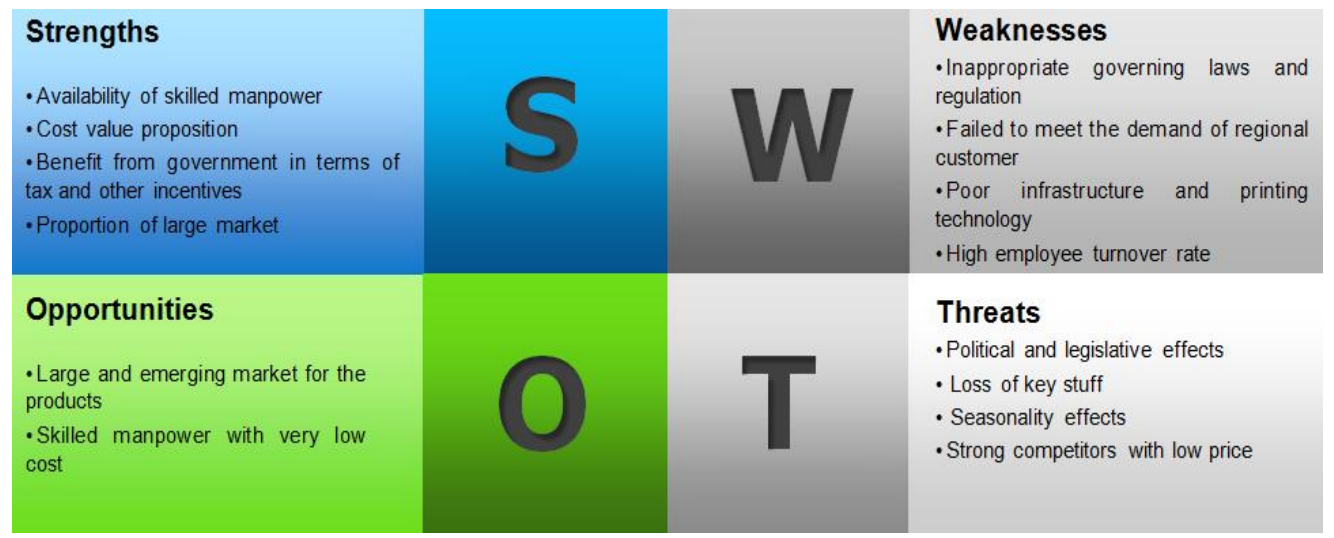

\section{CONCLUSION}

The printing and graphic arts industry in Sylhet are revolved in recent year. Local entrepreneurs are now interested in investing this industry, and many firms are emerged here as a leading service provider in the country in that industry. Each of the segments of this industry has some difficulties in their initial investment, operating a business and customer services. Lack of government support also hinders the development of this industry. Even in getting the supports available one has to face huge corruption and requires excessive lobbying. In our time, customer response is increasing in comparison to previous sessions of the business and most of the firms nearly 60.38 percent of this industry are earning profits while only 16.98 percent firms' incurred loss in their business operation. This above data reveals that this industry is very much profitable.

Competition increase chronologically with times in this industry which is a good sign as this helps to enhance the quality of product and service. But at the same time huge customer dues and insufficient raw materials along with a lack of related accessories are major hindrances in the development of this industry. Government should take proper initiative to alleviate the constraints of this industry.

\section{Reference}

Aktar MA. Green Insights of Textile Industry in Bangladesh: A Case Study on Mozart Knitting Ltd. Global Disclosure of Economics and Business. 2014;3(2):45-60.

BMSS. (2014). About BMSS. Retrieved August 25, 2014, from Bangladesh Mudran Shilpa Samity: http:/ / www.bmss-bd.org/about_bmss.php?title=History\%20Of\%20BMSS

IBSA. (2013). IBSA Environment Scan-2013. Environment Scan-2013 Printing E Graphic Arts Industry, 13. Australia: Industry Skills Councils \& Department of Industry Innovation, Science, Research and Tertiary Education.

McLuhan, M. (1962). The Gutenberg Galaxy: The Making of Typographic Man. London: University of Toronto Press.

Rahman, M. F. (2011, July 13). Printing: the next big thing for Bangladesh. Retrieved August 21, 2014, from The Daily Star: http:/ / archive.thedailystar.net/newDesign/news-details.php?nid=193962

Smyth, S. (2010). The Future of European printing to 2015, Market Forecast. Surrey: Pira International Ltd.

Vehmas, K., Kariniemi, M., Linna, H., Jokiaho, K., \& Esa. (2011). Future of European Printing. Espoo: VTT Technical Research Centre of Finland.

Weber, J. (2006). Strassburg, 1605: The Origins of the Newspaper in Europe. German History, 24 (3), 387-412. 